\title{
Effects of climate change and land management on soil organic carbon dynamics and carbon leaching in northwestern Europe
}

\author{
Maria Stergiadi ${ }^{1}$, Marcel van der Perk ${ }^{1}$, Ton C. M. de Nijs ${ }^{2}$, and Marc F. P. Bierkens ${ }^{1,3}$ \\ ${ }^{1}$ Department of Physical Geography, Faculty of Geosciences, Utrecht University, Heidelberglaan 2, \\ 3584 CS Utrecht, the Netherlands \\ ${ }^{2}$ National Institute for Public Health and the Environment (RIVM), P.O. Box 1, 3720 BA Bilthoven, the Netherlands \\ ${ }^{3}$ Unit Soil and Groundwater Systems, Deltares, Princetonlaan 6, 3584 CB Utrecht, the Netherlands
}

Correspondence to: Marcel van der Perk (m.vanderperk@uu.nl)

Received: 3 October 2015 - Published in Biogeosciences Discuss.: 10 December 2015

Revised: 25 February 2016 - Accepted: 26 February 2016 - Published: 11 March 2016

\begin{abstract}
Climate change and land management practices are projected to significantly affect soil organic carbon (SOC) dynamics and dissolved organic carbon (DOC) leaching from soils. In this modelling study, we adopted the Century model to simulate past (1906-2012), present, and future (2013-2100) SOC and DOC levels for sandy and loamy soils typical of northwestern European conditions under three land use types (forest, grassland, and arable land) and several future scenarios addressing climate change and land management change. To our knowledge, this is the first time that the Century model has been applied to assess the effects of climate change and land management on DOC concentrations and leaching rates, which, in combination with SOC, play a major role in metal transport through soil. The simulated current SOC levels were generally in line with the observed values for the different kinds of soil and land use types. The climate change scenarios result in a decrease in both SOC and DOC for the agricultural systems, whereas for the forest systems, SOC is projected to slightly increase and DOC to decrease. An analysis of the sole effects of changes in temperature and changes in precipitation showed that, for SOC, the temperature effect predominates over the precipitation effect, whereas for DOC the precipitation effect is more prominent. A reduction in the application rates of fertilisers under the land management scenario leads to a decrease in the SOC stocks and the DOC leaching rates for the arable land systems, but it has a negligible effect on SOC and DOC levels for the grassland systems. Our study demonstrated the
\end{abstract}

ability of the Century model to simulate climate change and agricultural management effects on SOC dynamics and DOC leaching, providing a robust tool for the assessment of carbon sequestration and the implications for contaminant transport in soils.

\section{Introduction}

Soil organic carbon (SOC) is an important component of the global carbon cycle, as it is one of the largest carbon reservoirs that exchanges actively with atmospheric carbon dioxide at timescales of human concern (Schimel, 1995; Baldock, 2007). Its paramount role in soil fertility and soil biodiversity has been recognised in many studies and its management is a critical factor for crop production (Reeves, 1997; Schlesinger, 2000). Moreover, soil organic matter (SOM) and dissolved organic carbon (DOC) can affect the transport of toxic substances, like heavy metals, through soil (Sauvé et al., 2000; Römkens et al., 2004; Unamuno et al., 2009; Groenenberg et al., 2012).

The major role of soil organic matter in metal mobility has been demonstrated by many studies (Elliott et al., 1986; Driscoll et al., 1988; Sauvé et al., 2000), as it promotes metal sorption in soil, thereby reducing metal bioavailability (Impellitteri et al., 2002). However, DOC has been associated with reduced metal retention and thus with facilitated metal transport in soil through the formation of organometal- 
lic complexes in the soil solution (Guisquiani et al., 1998; Römkens et al., 1999; Dijkstra et al., 2004). Climate- and land-management-induced changes in SOC and DOC levels can be associated with the transport of heavy metals, as well as pathogenic microorganisms, ultimately affecting the exposure of humans and ecosystems to these contaminants (Schijven and De Roda Husman, 2005).

Climate parameters have been proven to play a crucial role in the soil mechanisms controlling SOC decomposition (Jenny, 1980; Paul, 1984; Trumbore et al., 1996; Baldock, 2007; Conant et al., 2008; Álvaro-Fuentes et al., 2012a) and DOC leaching from soil (Harrison et al., 2008). Global climate models project the global mean temperature to increase by 1 to $6^{\circ} \mathrm{C}$ for the year 2100, compared to 1990 (IPCC, 2007). Most probably, the average temperature in Europe will increase slightly more rapidly than the world average, with winter temperatures increasing faster than the world average in northern Europe and summer temperatures increasing faster than the world average in southern Europe (IPCC, 2007). The projected rainfall patterns show seasonal variation across Europe, with wetter winters for northern Europe and dryer summers for southern Europe (IPCC, 2007; Christensen et al., 2011).

The response of SOC contents to climate change has been widely investigated at the regional (Liski et al., 2002; Smith et al., 2005, 2006; Álvaro-Fuentes et al., 2012a) and the global scale (Schlesinger and Andrews, 2000; Cramer et al., 2001; Davidson and Janssens, 2006; Gottschalk et al., 2012). Both positive (Liski et al., 2002; Álvaro-Fuentes et al., 2012a; Gottschalk et al., 2012) and negative responses (Cramer et al., 2001; Smith et al., 2005) have been reported. Changes in temperature-mediated DOC draining from soil have been suggested as a potential factor influencing DOC concentration in rivers (Worrall et al., 2003). Alterations of hydrological parameters due to climate change have also been associated with changes in DOC leaching through the soil profile, indicating that changes in the precipitation patterns can strongly influence the leaching rates of DOC (Tranvik et al., 2002; Harrison et al., 2008).

Land management practices have been recognised as propitious strategies for counterbalancing the anthropogenic carbon dioxide emissions through SOC sequestration (Burke et al., 1995; Paustian at al., 1997b; Post et al., 1999; Lal, 2004). The use of fertilisers has been associated with enhanced carbon sequestration in agricultural soils due to increased crop production and associated carbon inputs into the soil (Paustian et al., 1997a; Lal, 2004; Álvaro-Fuentes et al., 2012b). However, climate conditions, soil type, and land management can strongly influence the systems' response to fertilisation (Glendining and Powlson, 1991; Alvarez, 2005), resulting in ambiguous effects of fertilisation on SOC levels (Khan et al., 2007; Reid, 2008).

Alvarez (2005) reviewed published data from field experiments worldwide in order to evaluate the effects of nitrogen fertilisation on SOC levels. He observed both positive and negative responses of SOC to nitrogen fertilisers. Paustian et al. (1996) suggested that land management was an essential factor determining SOC dynamics under changing climate in the USA. Their SOC projections for agricultural systems under climate change and land management change scenarios revealed that management practices had a greater influence on SOC levels than climate change. The number of studies concerning the effects of fertilisation on DOC is limited. Ruark et al. (2009) and Walmsley et al. (2011) suggested that changes in the fertilisation rates caused no influence on DOC leaching from soil. In contrast, Adams et al. (2005) found a potential increase in DOC leaching through the soil profile caused by nitrogen fertilisation treatments in forest systems. Apart from climate and land management, land use history is a critical factor determining SOC stocks. The response of SOC to land use change is rather slow due to the slow SOC turnover of the major SOC pools (Verheyen et al., 1999; Sonneveld et al., 2002; Schulp and Verburg, 2009).

The above studies show that the response of SOC and DOC to climate change and land management is complex and equivocal and depends on a variety of factors, including soil properties and land use history. Therefore, for a realistic assessment of SOC and DOC levels and possible changes thereof, these factors should be taken into account.

This study aims to assess the effects of climate change and land management on SOC accumulation, SOC distribution across different pools, and DOC leaching for northwestern European conditions. For this purpose, we used the Century model (Parton et al., 1987, 1988, 1993) to simulate past (1906-2012), present, and future (2013-2100) SOC and DOC levels in sandy and loamy soils under three generalized land use types (forest, grassland, and arable land) typical for the Quaternary fluvial, glacial, and aeolian deposits in northwestern Europe. For the simulation of future development of SOC and DOC levels, we adopted four future climate scenarios of the Royal Dutch Meteorological Institute (KNMI, 2006) and a land management scenario. The climate scenarios project average temperatures to rise and seasonal patterns of precipitation to change resulting in dryer summers and wetter winters in the Netherlands and surrounding countries. The land management scenario accounted for the implementation of the EU guidelines concerning the maximum levels of nutrients added to the soil (Alterra, 2011). To our knowledge, this is the first time that the Century model has been applied to assess the effects of climate change and land management on DOC in soil.

\section{Materials and methods}

\subsection{Model description}

The key mechanisms that control organic matter dynamics in soil can be adequately simulated by computer models (Paustian et al., 1992). The Century model, developed by Parton 
et al. $(1987,1988,1993)$, is one of the most commonly used soil organic matter models worldwide. Century is a processbased biogeochemical model that simulates the dynamics of carbon $(\mathrm{C})$, nitrogen $(\mathrm{N})$, phosphorus $(\mathrm{P})$, and sulfur $(\mathrm{S})$ through an annual cycle to millennia in the top $20 \mathrm{~cm}$ of the soil profile. The model has different plant production submodels for grassland/agricultural land and for forest systems, both linked to a common soil organic matter submodel, allowing the simulation of a wide range of natural and cultivated systems such as grassland, arable land, forest, and savanna systems. A water budget submodel is incorporated to calculate water loss and fluxes. The various submodels that constitute the Century model have been described in detail by Parton et al. (1987, 1988, 1993) and Metherell et al. (1993). For this study, we applied version 4.6 of the Century model.

The model runs on a monthly time step, requiring input information on climate (temperature and precipitation), soil properties (soil texture, soil $\mathrm{pH}$, bulk density, field capacity, wilting point, initial organic and mineral soil $\mathrm{C}, \mathrm{N}, \mathrm{P}$, and S), and plant chemistry characteristics (e.g. lignin content, nutrient content). Management practices (e.g. cropping, fertilisation, cultivation, grazing, irrigation) and abrupt events (e.g. fire, tree removal) can also be included in the model.

In the Century model, the grassland/crop production submodel simulates plant production for different herbaceous crops and plant communities. The plant production submodel has carbon and nutrient pools for live shoots and roots and standing dead plant material. Harvest, grazing, fire, and cultivation directly affect aboveground biomass, while grazing and fire may also influence root to shoot ratios and nutrient content. At harvest, grain is removed from the system and live shoots can either be removed or transferred to standing dead and surface residue. The forest submodel simulates the growth of deciduous or coniferous forests in juvenile and mature phases. It allocates carbon and nutrients to leaves, fine roots, fine branches, large wood, and coarse roots using a fixed allocation scheme. In both plant production submodels, the monthly plant production is controlled by a maximum production defined for each plant or crop, soil moisture, nutrient supply, and temperature. In addition, in the forest submodel, the monthly plant production also depends on the live leaf area index and in the grassland/crop production submodel, the monthly plant production is also affected by shading by dead vegetation and seedlings (Metherell et al., 1993).

Soil organic matter and plant residues are partitioned into different conceptual pools according to their potential decomposition rate. These pools do not fully correspond with analytical soil organic matter fractions based on physical or chemical properties (Metherell et al., 1995). Surface litter and root litter are divided into structural (resistant to decomposition) and metabolic (easily decomposable) material, depending on their lignin to nitrogen ratio. In the Century 4.6 model, soil organic matter partitions among two surface pools (an active pool, with a turnover time of several years, and a slow pool, with a turnover time of $20-50$ years) and three soil pools (active, slow, and passive, with the latter having a turnover time of 400-2000 years). The actual turnover rates of these pools are a function of soil temperature, soil moisture, soil $\mathrm{pH}$, cultivation effects, and, for the active pool, soil texture.

Part of the products from decomposition of the active pool is lost as leached DOC. The loss of leached DOC from the top $20 \mathrm{~cm}$ of the soil profile is positively related to the decay rate for active SOM and the water drainage rate from the soil profile up to a critical level and is inversely related to the clay content.

\subsection{Model input and calculations}

In this study, the Century model was used to simulate past (1906-2012), present, and future (2013-2100) SOC and DOC levels in sandy and loamy soils under three generalized land use types (grassland, arable land, and forest). The soil properties, land use types, and land management practices were selected to reflect ecosystems typical for northwestern European conditions. For the purposes of this study, the simultaneous cycles of $\mathrm{C}, \mathrm{N}$, and $\mathrm{P}$ were considered. The values of the plant- or crop-specific parameters, which determine plant production and the allocation of carbon and nutrients across the various pools in response to the site-specific conditions and events, were borrowed from the default parameter values for a range of crop and forest types, which were provided with the Century model (see also Metherell et al., 1993).

Table 1 shows the model input values regarding soil properties. Preliminary model calculations showed that the simulated SOC levels were especially sensitive to soil $\mathrm{pH}$ values. Therefore, additional model runs were performed for the simulated systems with soil $\mathrm{pH}$ values increased by $0.2 \mathrm{pH}$ units to assess the sensitivity of the simulated SOC levels to changes in soil $\mathrm{pH}$.

To estimate the initial conditions with respect to SOC, N, and $\mathrm{P}$ levels in soil and the partitioning across the various pools in 1906, the Century model was run for the period from $800 \mathrm{AD}$ onwards as a spin-up period, thereby taking into account the effects of land use history on the current and future SOC and DOC levels. This period was chosen because the different land use systems have resulted from a change in land use from deciduous forest to agricultural land or heathland (the latter only on sandy soils) that took place at around 800 AD due to increasing population growth (Spek, 2004; Kaplan et al., 2009; Bouman et al., 2013). To initialise the model simulations for the different land use types in $800 \mathrm{AD}$, the forest submodel was applied for a period of several thousands of years to estimate the equilibrium levels of soil organic matter $(\mathrm{C}, \mathrm{N}$, and $\mathrm{P})$ for the native deciduous forest system without any natural or anthropogenic disturbances, such as fire or logging. We assumed that the simulated systems have not undergone land use changes since $800 \mathrm{AD}$, 
Table 1. Model input soil properties for the different generalized land use types and soil types.

\begin{tabular}{|c|c|c|c|}
\hline & Sandy soil & Loamy soil & Reference \\
\hline Soil texture & & & De Bakker (1979) \\
\hline Sand, $\%$ & 75.0 & 18.0 & \\
\hline Clay, \% & 4.0 & 9.0 & \\
\hline Silt, \% & 21.0 & 73.0 & \\
\hline Bulk density ${ }^{\mathrm{a}}, \mathrm{g} \mathrm{cm}^{-3}$ & 1.57 & 1.36 & Century model soil calculator \\
\hline $\mathrm{pH}$ & & & Province of Noord-Brabant (1996); Bodemdata (2014); RIVM (2014) \\
\hline Grassland & 5.1 & 6.2 & \\
\hline Arable land & 5.1 & 6.1 & \\
\hline Forest & 3.2 & 4.5 & \\
\hline Heathland ${ }^{\mathrm{b}}$ & 3.2 & - & \\
\hline Soil drainage class ${ }^{\mathrm{c}}$ & & & Century model parameterization workbook \\
\hline Grassland and arable land & 0.75 & 0.75 & \\
\hline Forest & 1.00 & 1.00 & \\
\hline Heathland ${ }^{b}$ & 1.00 & - & \\
\hline
\end{tabular}
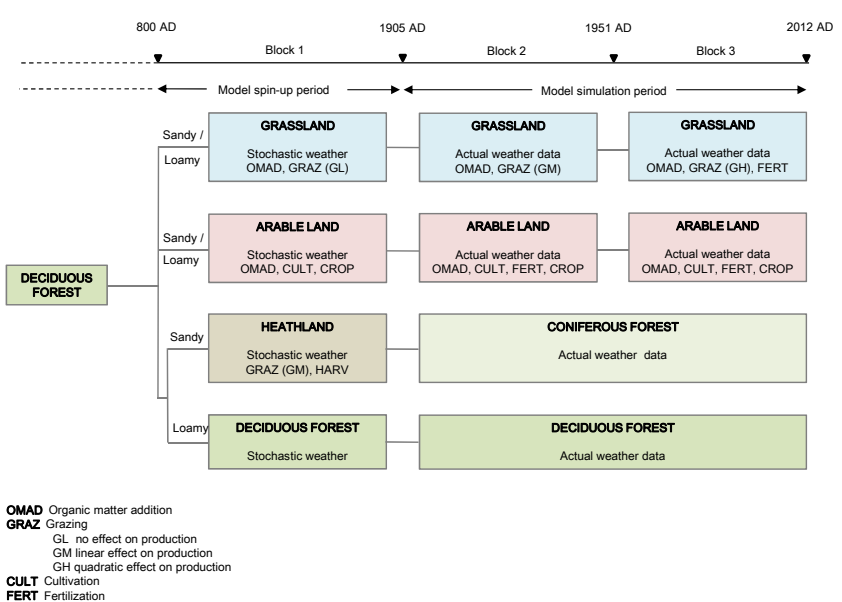

FERT Fervilizition
CROP Crop planted

Figure 1. Scheme of the Century modelling procedure.

except for the forest system on sandy soils. This system was simulated as a heathland system for the period $800-1905$, before it was converted to coniferous forest around 1900 (CBS, 2014a).

Figure 1 provides an overview of the simulated periods of time (blocks) and the scheduled land management events for the different land use types. Each block in the Century model represents a period of time within which climate parameters and land management practices were left unchanged. Model input concerning past and present land management practices was based on the Dutch Central Bureau for Statistics (CBS, 2014b) and expert judgement.

For the heathland system on sandy soil during the model spin-up period (Block 1), the event scheduling included grazing and removal of aboveground biomass to be used as fer- tiliser in the sandy arable land system. The latter was simulated as harvesting in order to imitate the litter layer removal, which nevertheless cannot be fully accounted for in the Century model.

In the grassland systems on both soil types, organic matter addition was simulated using the default straw manure option with a rate of $300 \mathrm{~g} \mathrm{~m}^{-2} \mathrm{yr}^{-1}$. The simulated grazing intensity was considered to gradually increase in the course of time, being low (no direct effect on biomass production) for the period 800-1905 (Block 1; model spin-up period), moderate (linear effect on biomass production) for the period 1906-1950 (Block 2), and high (quadratic effect on biomass production) for the period 1951-2012 (Block 3). Application of mineral fertilisers was accounted for after 1950, equalling $300 \mathrm{~kg} \mathrm{ha}^{-1} \mathrm{yr}^{-1}$ nitrogen and $40 \mathrm{~kg} \mathrm{ha}^{-1} \mathrm{yr}^{-1}$ phosphorus.

In the arable land systems, the simulated organic fertiliser addition varied for the two different soil types. For the sandy soil system, the organic fertiliser addition for the period 8001905 (Block 1; model spin-up period) was simulated as a mixture of straw manure and heath plaggen originating from sod cutting in the heathland system (Schulp and Verburg, 2009), as mentioned above. Until the beginning of the 20th century, the amount of organic matter added in this system was $520 \mathrm{~g} \mathrm{~m}^{-2} \mathrm{yr}^{-1}$ (Schulp and Verburg, 2009). Based on the default lignin content of straw manure $(25 \%)$ and the simulated lignin content of heather litter, the lignin content of the organic mixture was estimated to be $43 \%$. For the sandy arable land system after 1905, as well as for the loamy soil system for the entire simulation period, the simulated manure added consisted only of straw manure, amounting to nearly $30 \%$ of the amount added in the grassland systems.

For the arable land systems on both soil types, 2-year crop rotation schemes consisting of wheat and potatoes were 
considered until the first half of the 20th century (Blocks 1 and 2), whereas 4-year crop rotation schemes also including sugar beets and maize were simulated for the period after that (1952-2011) (CBS, 2014b). Application of mineral fertilisers in these systems was introduced at the beginning of the 20th century, with mineral nitrogen amounts increasing by a factor of 10 after 1950 and mineral phosphorus increasing by a factor of 2, reaching a value of 150 and $40 \mathrm{~kg} \mathrm{ha}^{-1} \mathrm{yr}^{-1}$ respectively (Knibbe, 2000). Tillage practices in these systems consisted of annual ploughing, which caused an increase in soil organic matter decomposition by a factor 1.6 during the month of cultivation (February).

Meteorological data (minimum and maximum monthly temperatures, monthly precipitation rates) were based on monitoring data from the KNMI for the period 1925-2012. The climate reconstruction for the model initialization (before $800 \mathrm{AD}$ ), as well as for the model simulations for the period 800-1905 (spin-up period), was based on scaling factors calculated by data reported by Brandsma and Buishand (1996) and Van Engelen et al. (2001) (Table S1 in the Supplement). For the period before 1905, the model was forced by repeated mean minimum and maximum temperatures for every year and stochastically generated precipitation from a skewed distribution. For the period 1906-2012, actual weather data from the KNMI were used.

The most important Century model outputs include total average SOC levels, SOC fractionation in different pools in the top $20 \mathrm{~cm}$ of the soil profile, and DOC leaching from this soil layer. The DOC concentrations were calculated as annual average flow-weighted concentrations in the leachate. The simulated current SOC levels were compared to observed SOC values derived from various Dutch soil databases for the different land use types and soil types (Province of Noord-Brabant, 1996; Bodemdata, 2014; RIVM, 2014), taking into account the different soil depths the simulated and observed values referred to. For this correction for different soil depths, we converted the observed values for grassland and forest sites using SOC depth distribution data reported for grasslands (Don et al., 2007) and forests (Braakhekke et al., 2013) in Germany and the Netherlands. The observed SOC values for arable were not converted since the SOC distribution within the soil profile of arable land systems can be assumed to be quite homogenous in the top $20 \mathrm{~cm}$ of soil due to ploughing (De Bakker, 1979).

\subsection{Climate change and land management change scenarios}

\subsubsection{Climate change scenarios}

Based on research outcomes concerning global temperature changes and changes in atmospheric circulation over Western Europe, the KNMI (2006) developed four future climate scenarios for the Netherlands, which are considered to comprise the possible range of future climate change (Van den
Hurk et al., 2006). These scenarios were evaluated in 2009 by testing the models in line with more recent national and international scientific advances and were found to be still representative of the most likely anticipated climate changes (KNMI, 2009).

The expected changes until the end of the 21 st century, as projected by the KNMI (2006) for the Netherlands, comprise of

- rising air temperature

- wetter winters with increased precipitation amounts

- hotter and dryer summers with increased intensity of extreme rain showers and less rainy days

- small changes in wind in comparison to the natural fluctuations.

The scenarios selected for the purpose of this study consisted of the $\mathrm{G}+$ and $\mathrm{W}+$ scenarios, which refer to the more extreme future predictions that concern important change in air circulation patterns. Compared to the year 1990 the respective climate scenarios involve a global temperature rise by $2{ }^{\circ} \mathrm{C}$ by 2100 in the $\mathrm{G}+$ scenario and $4{ }^{\circ} \mathrm{C}$ in the $\mathrm{W}+$ scenario. Seasonal temperature and precipitation changes in northwestern Europe for these scenarios are summarised in Table 2. For more details about the scenarios we refer to KNMI (2006, 2009) and Lenderink et al. (2007).

To obtain a continuous time series of mean monthly temperature and precipitation for the period 2013-2100 (W+ cc $T, P$ and $\mathrm{G}+\operatorname{cc} T, P$ scenarios), the historic time series for the 10-year period around 1990 (1985-1994) was transformed according to the $\mathrm{G}+$ and the $\mathrm{W}+\mathrm{KNMI} 06$ scenarios for successive 10-year periods from 2010 to 2100 . The mean monthly minimum and maximum temperatures were calculated from the mean monthly temperatures using a regression relation established for the period 1990-2012. In the scenario calculations, the effects of increased atmospheric $\mathrm{CO}_{2}$ concentrations on plant growth were not taken into account.

To identify the individual effects of temperature and precipitation on SOC levels and DOC leaching rates, as well as the effects of no change in climate, three more scenarios involving no climate change (No cc), changes only in temperature $(\mathrm{W}+\mathrm{cc} T)$, and changes only in precipitation $(\mathrm{W}+\mathrm{cc}$ $P$ ) were run. The no-climate-change scenario data were derived from transforming the 10-year time series around 1990 to 2010 and using this time series for the subsequent decades until 2100. An overview is given in Table 2 of the annual averages for total precipitation and mean minimum and mean maximum temperatures for the period 2013-2100 and for the different climate change scenarios. In these simulations for the agricultural systems under the climate change scenarios, the land management practices were constant for the period 1951-2100. 
Table 2. Changes in temperature and precipitation during winter and summer between the reference year 1990 and 2100 , as well as annual precipitation, mean monthly minimum $\left(T_{\min }\right)$, and mean monthly maximum $\left(T_{\max }\right)$ temperatures in 2100 for the different climate change scenarios.

\begin{tabular}{lrr|rr|rrr}
\hline Climate change scenario & \multicolumn{2}{c|}{$\Delta$ Temp } & \multicolumn{2}{c|}{$\Delta$ Prec } & Tempmin & Tempmax & Prec \\
\cline { 2 - 7 } & winter & summer & winter & summer & $\left({ }^{\circ} \mathrm{C}\right)$ & $\left({ }^{\circ} \mathrm{C}\right)$ & $\left(\mathrm{mm} \mathrm{yr}^{-1}\right)$ \\
\hline No cc & $0{ }^{\circ} \mathrm{C}$ & 0 & 0 & 0 & 6.5 & 14.8 & 850 \\
$\mathrm{~W}+\mathrm{cc} T, P^{\mathrm{b}}$ & $+4.6{ }^{\circ} \mathrm{C}$ & $+5.6{ }^{\circ} \mathrm{C}$ & $+28 \%$ & $-38 \%$ & 8.4 & 17.4 & 825 \\
$\mathrm{~W}+\mathrm{cc} T^{\mathrm{c}}$ & $+4.6{ }^{\circ} \mathrm{C}$ & $+5.6^{\circ} \mathrm{C}$ & 0 & 0 & 8.4 & 17.4 & 850 \\
$\mathrm{~W}+\mathrm{cc} P^{\mathrm{d}}$ & 0 & 0 & $+28 \%$ & $-38 \%$ & 6.5 & 14.8 & 825 \\
$\mathrm{G}+\mathrm{cc} T, P^{\mathrm{e}}$ & $+2.3{ }^{\circ} \mathrm{C}$ & $+2.8^{\circ} \mathrm{C}$ & $+14 \%$ & $-19 \%$ & 7.0 & 15.6 & 839 \\
\hline
\end{tabular}

${ }^{\mathrm{a}}$ No-climate-change scenario. ${ }^{\mathrm{b}} \mathrm{W}+$ climate change scenario, considering changes in both temperature $(T)$ and precipitation $(P) .{ }^{\mathrm{c}} \mathrm{W}+$ climate change scenario, considering changes only in temperature $(T) .{ }^{\mathrm{d}} \mathrm{W}+$ climate change scenario, considering changes only in precipitation $(P)$.

${ }^{\mathrm{e}} \mathrm{G}+$ climate change scenario, considering changes in both temperature $(T)$ and precipitation $(P)$.

\subsubsection{Land management change scenarios}

For both the grassland systems and the arable land systems, the land management change scenarios $(\mathrm{G}+\mathrm{cc} \mathrm{RF}$ and $\mathrm{W}+$ $\mathrm{cc} \mathrm{RF})$ were related to a change in the application rates of organic and inorganic fertilisers under the $\mathrm{G}+$ and $\mathrm{W}+$ climate change scenarios respectively. For the two systems, the future (2013-2100) application rate for nitrogen via manure was kept the same as in the period 1951-2012, while the application rate for phosphorus was reduced by $20 \%$ due to declining phosphorus levels in fodder (LTO, 2013). The inorganic nitrogen fertilisation rate for the period 2013-2100 was reduced by nearly $60 \%$ in the grassland systems and by nearly $20 \%$ in the arable land systems in comparison to the rates in the period 1951-2012. The simulated reductions were made in order to comply with the nitrogen application standards provided by the Dutch Ministry of Economic Affairs, Agriculture and Innovation (2011), which are based on the EU Nitrates Directive (Commission of the European Communities, 1991) concerning the protection of waters against pollution caused by nitrates from agricultural sources.

The projected total phosphorus application rates on agricultural land were based on the EU Common Agricultural Policy (Alterra, 2011) and equalled the amount of phosphorus that is being removed, by either grazing or harvest. Preliminary Century model results for the present conditions in the grassland systems showed that the amount of phosphorus returned to the soil during grazing was nearly equal to the amount of phosphorus removed by standing dead and live shoots by livestock. For this reason and for the future scenarios in these systems, no phosphorus via artificial fertilisers was added. Following the same procedure for the arable land systems, the amount of phosphorus added via inorganic fertilisers in the future simulations was reduced by almost $80 \%$.

\section{Results and discussion}

\subsection{Historic development}

The simulation results regarding the development of the major SOC pools $(0-20 \mathrm{~cm})$ for the period 1906-2012 and for the different land use types and soil types are presented in Fig. 2 (plot data are given in Tables S1-S6 in the Supplement). Figure 3 shows the trends for DOC concentrations for the same systems (plot data are given in Tables S7-S12 in the Supplement). For the period 1906-2012, SOC levels (Fig. 2) and DOC concentrations (Fig. 3) show contrasting trends for the different soil and land use types, with strong interannual variations for the DOC concentrations. SOC and DOC levels in grassland systems remained nearly constant throughout the period 1906-2012, with average values around $1.16 \%$ for SOC and $9.3 \mathrm{mg} \mathrm{L}^{-1}$ for DOC for the system on sandy soil and $1.52 \%$ SOC and $4.4 \mathrm{mg} \mathrm{L}^{-1}$ DOC for the system on loamy soil. In the first half of the 20th century, SOC and DOC levels in the arable land system on sandy soil decreased considerably from 2.41 to $1.30 \%$ for SOC, with a further decline to $1.02 \%$ in 2012 , and from 21.0 to $15.0 \mathrm{mg} \mathrm{L}^{-1}$ for DOC during the entire period 1906-2012. In the arable land system on loamy soil, both SOC and DOC showed an increasing trend from 0.90 to $1.32 \%$ for SOC and from 5.0 to $7.0 \mathrm{mg} \mathrm{L}^{-1}$ for DOC for the period 1906-2012. The SOC levels in the forest system on sandy soil also showed an increasing trend from 2.60 to $2.86 \%$, whereas the SOC levels in the forest system on loamy soil remained constant at a level just above $0.63 \%$. DOC concentrations for the forest system on sandy soil decreased considerably from 20.0 to $3.0 \mathrm{mg} \mathrm{L}^{-1}$ during the period 1906-1920, remaining nearly constant for the period after 1920, whereas DOC shows a steady trend at around $1.7 \mathrm{mg} \mathrm{L}^{-1}$ for the forest system on loamy soil. In both the arable land system and the forest system on sandy soil, the SOC levels did not seem to have reached equilibrium conditions by 2012 .

The decline in SOC and DOC in the sandy arable land system just after 1900 (Figs. 2 and 3) can mainly be attributed 

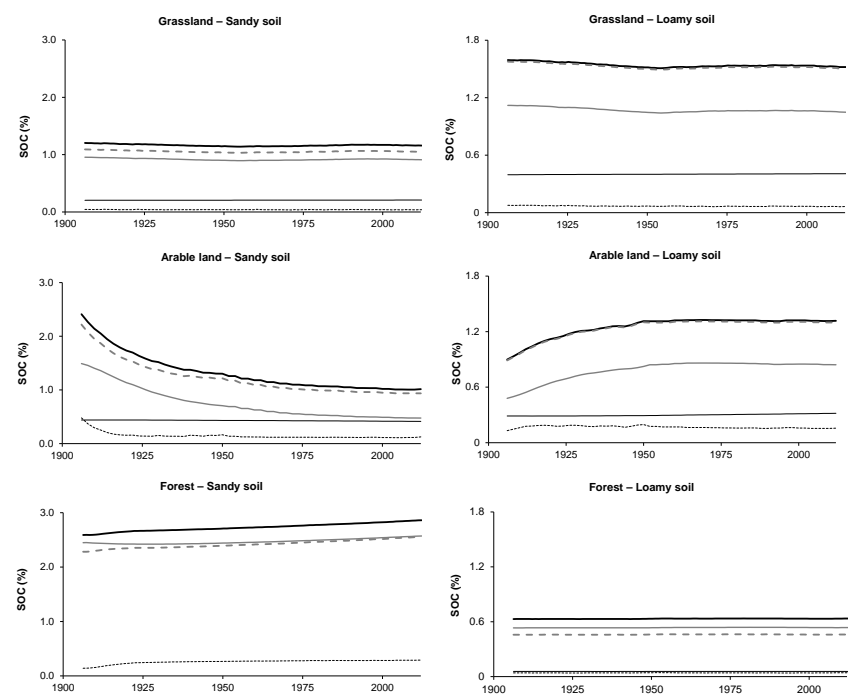

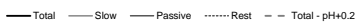

Figure 2. Changes in SOC stocks $(0-20 \mathrm{~cm})$ in grassland systems, arable land systems, and forest systems on sandy and loamy soil for the period 1906-2012. Total SOC levels, as well as the size of the individual pools, are shown. "Rest" refers to the sum of SOC in the smaller pools (sum of active, structural, and metabolic pools for all systems, except for the forest system on sandy soil for which "rest" also includes the passive pool). The dotted line represents the change in total SOC for increased soil $\mathrm{pH}$ by $0.2 \mathrm{pH}$ units. Note the difference in scale of the vertical axes between the sandy and loamy soil.

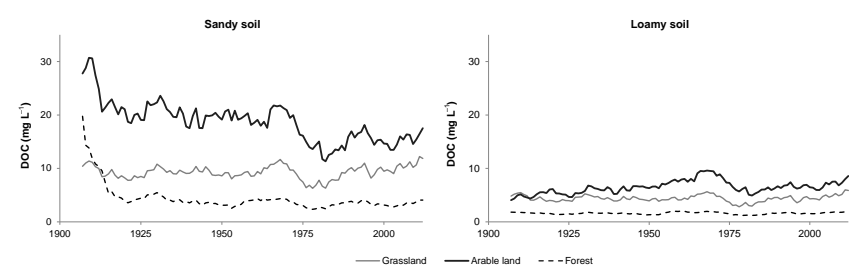

Figure 3. Changes in DOC concentrations (8-year moving averages) in grassland systems, arable land systems, and forest systems on sandy and loamy soil for the period 1906-2012.

to the drastic reduction in the application rate of manure by almost $80 \%$ around 1900 . In contrast, the application of manure in the arable land system on loamy soil remained constant throughout the simulation period. The increase in SOC and DOC in this system at the beginning of the 20th century was mainly caused by the introduction of artificial fertilisers (Figs. 2 and 3). The application of artificial fertilisers in the grassland systems and the arable land systems after 1950 caused no notable alterations in the SOC and DOC levels.

The increase in SOC levels in the sandy forest system can be mainly associated with the change in land use from heathland to forest that took place around 1900. This change in land use also gave rise to a sharp decline in DOC concentra- tions for the sandy forest system at the beginning of the 20th century.

For all systems, the simulated total SOC levels remained nearly constant from about 1980 . Only slight total SOC gains were simulated for the grassland systems and for the forest system on sandy soil, whereas negligible total SOC losses were simulated for the arable land systems and for the forest system on loamy soil. These gains and losses in SOC levels were on the order of $2-27 \mathrm{mg} \mathrm{kg}^{-1} \mathrm{yr}^{-1}$.

Our outcomes are in line with previous observational studies (Reijneveld et al., 2009; Hanegraaf et al., 2009) and model studies (Vleeshouwers and Verhagen, 2002), which reported on average small SOC decreasing trends for arable lands and small increasing trends for grasslands. Our study showed that this latter trend is also true for forest systems on sandy soils and that, in contrast to reports raising concerns regarding SOC losses in European agricultural soils, e.g. in Belgium (Sleutel et al., 2003; Meersmans et al., 2009), Norway (Riley and Bakkegard, 2006), southern Germany (Capriel, 2013), and Finland (Heikkinen et al., 2013), the risk for significant SOC decline in sandy and loamy soils in northwestern Europe is low.

\subsection{Current levels}

Figure 2 shows that the simulated current SOC levels for the grassland systems were higher than for the arable land systems, whereas the highest SOC levels among all systems were predicted for the forest system on sandy soil. The lowest SOC levels were predicted for the forest system on loamy soil. DOC concentrations were found to be higher in the agricultural systems and especially in the arable land systems (Fig. 3). For all systems, the largest amount of total SOC is present in the slow pool, followed by the passive pool (Table 3). The significantly large passive pool simulated for the arable land system on sandy soil is associated with the historic land management practices for this system, with application of vast amounts of organic fertilisers (straw manure and heath plaggen). For the forest systems, nearly all of the SOC resides in the slow pool.

The results of the $\mathrm{pH}$-sensitivity analysis show that an increase in soil $\mathrm{pH}$ by $0.2 \mathrm{pH}$ units lead to a decline in total SOC for all systems (Table 4), with the decrease being more pronounced for the forest systems and the agricultural systems on sandy soil, which are more acidic. The reduction in total SOC is related to a reduction in the size of the slow pool. The passive pool, consisting of recalcitrant material that turns over very slowly, remains nearly constant for all cases, also under changing soil $\mathrm{pH}$ and fertiliser application rates.

Comparison between the simulated SOC levels and observed values corrected for the differences in sampling depths (Table 5) shows that the Century model underestimated the observed SOC levels. Only the simulated SOC values for the loamy arable land system and the sandy forest system are within the measured ranges. For all considered 
Table 3. Simulated fractionation of SOC (\% of total SOC) in the different pools for the three generalized land use types for the year 2012.

\begin{tabular}{lrr|rr|rr}
\hline & \multicolumn{2}{c|}{ Grassland } & \multicolumn{2}{c|}{ Arable land } & \multicolumn{2}{c}{ Forest } \\
\cline { 2 - 7 } & sandy & loamy & sandy & loamy & sandy & loamy \\
\hline Active pool & 2 & 3 & 3 & 5 & 4 & 4 \\
Slow pool & 79 & 69 & 47 & 64 & 90 & 84 \\
Passive pool & 18 & 27 & 41 & 24 & 2 & 9 \\
Rest & 1 & 1 & 9 & 7 & 4 & 3 \\
\hline
\end{tabular}

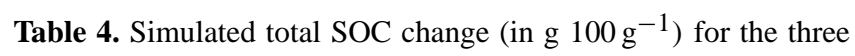
generalized land use types for an increase in soil $\mathrm{pH}$ by $0.2 \mathrm{pH}$ units, for the year 2012 .

\begin{tabular}{lc}
\hline $\begin{array}{l}\text { Land use type } \\
\text { grassland }\end{array}$ & SOC change, g $100 \mathrm{~g}^{-1}$ \\
\hline Sandy & -0.11 \\
Loamy & -0.02 \\
Arable land & \\
Sandy & -0.08 \\
Loamy & -0.02 \\
Forest & \\
Sandy & -0.31 \\
Loamy & -0.17 \\
\hline
\end{tabular}

systems, the mean bias error of the model predictions relative to the medians of the observed SOC contents is $-0.53 \%$

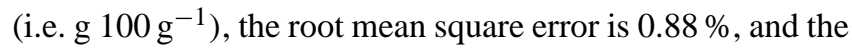
Pearson's correlation coefficient $(r)$ equals 0.35 .

The simulated SOC values for the grassland systems are slightly below the measured ranges. This underestimation could possibly be due to an underestimation of the organic carbon input by manure application, which was and is particularly high in the Province of Noord-Brabant in the Netherlands (De Walle and Sevenster, 1998), from which the majority of the observed SOC values were derived. In addition, the underestimation could also be caused by an overestimation of the water drainage from the topsoil compared to the measurement sites. Although the grassland systems were simulated as being somewhat poorly drained (see Table 1), a number of measured locations could have a poorer drainage status than simulated, which may considerably increase the SOC levels in the topsoil (Sonneveld and Van den Akker, 2011). The underestimation of SOC levels in the sandy arable system could be the result of an overestimation of the decomposition rates of organic matter derived from heath plaggen. The underestimation of the SOC levels in the loamy forest system may be attributed to the variability in soil $\mathrm{pH}$. The soil $\mathrm{pH}$ of loamy forest systems appears to be particularly variable (Bodemdata, 2014) and the SOC values are particularly sensitive to soil $\mathrm{pH}$ in forest systems (Fig. 2, Table 4).

The simulated current DOC concentrations are listed in Tables 6-8. Direct comparison between our model results and values reported in the literature is problematic since literature values of soil DOC concentrations observed at $20 \mathrm{~cm}$ depth in the systems considered in this study are scarce. Nevertheless, a few studies reported DOC concentrations for grassland, arable land, and forest sites in northwestern Europe. Kindler et al. (2011) studied DOC concentrations and leaching at 12 sites at for soil depths ranging from 5 to $40 \mathrm{~cm}$. They reported DOC concentration ranges of $1.9-17.1 \mathrm{mg} \mathrm{L}^{-1}$ for grasslands $(N=4), 3.9-17.3 \mathrm{mg} \mathrm{L}^{-1}$ for arable land $(N=3)$, and $7.1-43.1 \mathrm{mg} \mathrm{L}^{-1}$ for forests $(N=5)$. Michalzik et al. (2001) studied the DOC concentrations in temperate forests. The three northwestern European sites (Germany and Norway) for which DOC concentrations at depths ranging from 20 to $30 \mathrm{~cm}$ are reported show a range of $2.6-31.2 \mathrm{mg} \mathrm{L}^{-1}$. Van den Berg et al. (2012) measured DOC concentration ranges between 10.2 and $46.1 \mathrm{mg} \mathrm{L}^{-1}$ for forests $(N=11)$ and between 2.5 and $29.5 \mathrm{mg} \mathrm{L}^{-1}$ for grasslands $(N=18)$ in UK soils at sampling depths between 5 and $10 \mathrm{~cm}$. Van den Berg et al. (2012) also reported lower average DOC concentrations in medium and fine-textured Cambisols (mean $=17.4 \mathrm{mg} \mathrm{L}^{-1}$ ) than in coarser-grained Podzols (mean $=27.4 \mathrm{mg} \mathrm{L}^{-1}$ ). The above studies show broad ranges of DOC concentrations for the different land use classes, which may be related to site-specific factors, such as local climate, land management, soil $\mathrm{C}: \mathrm{N}$ ratio, soil texture, and sampling depth. The shallower sampling depth in the study by Van den Berg et al. (2012) is likely the reason that they found higher DOC values than the other studies. For the grassland and arable land systems, our model results fall within the ranges reported. However, for the forest systems, our model results generally fall in the lower range or below the reported ranges. This is probably due to the relatively low soil $\mathrm{C}: \mathrm{N}$ ratio in our simulated forest systems compared to the majority of forest soils for which observations are available.

\subsection{Future scenarios}

\subsubsection{Climate change scenarios}

Simulated SOC contents and DOC concentrations for the three systems show different trends for the different climate change scenarios (Tables 6-8, Fig. 4, plot data for Fig. 4 can be found in Tables S13-S18 in the Supplement). For the sim- 


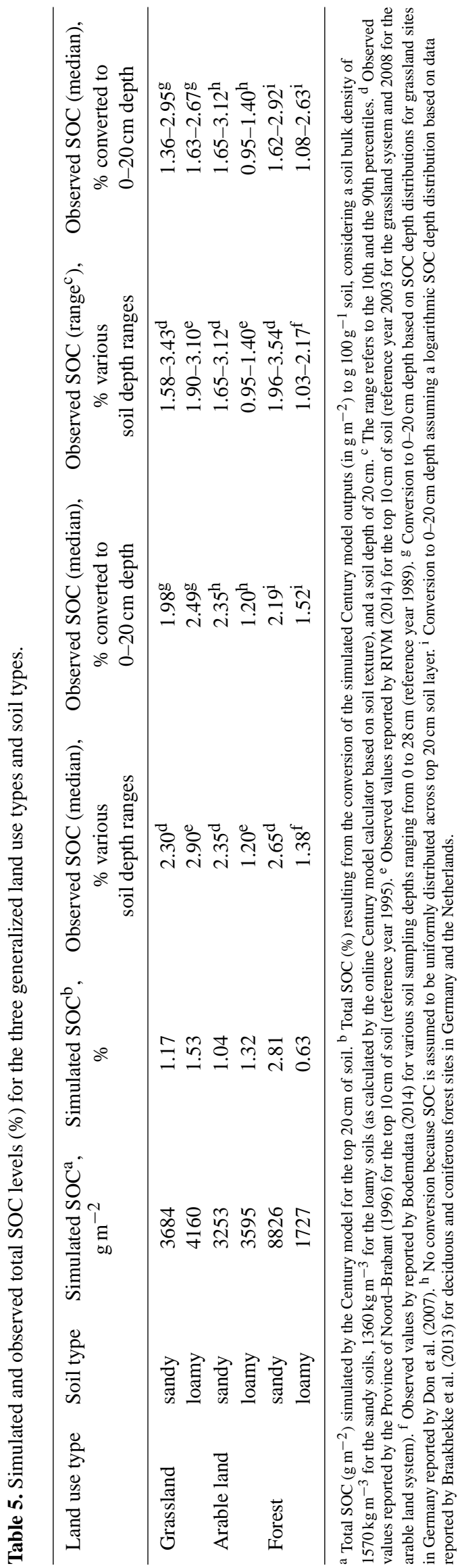

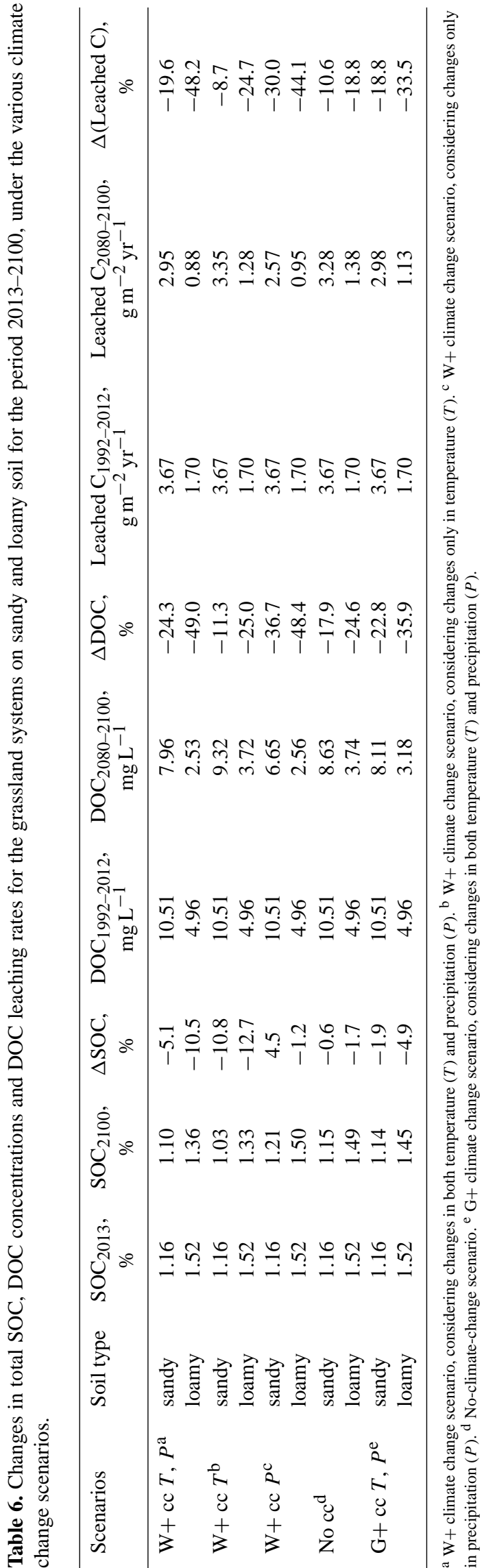

Biogeosciences, 13, 1519-1536, 2016 


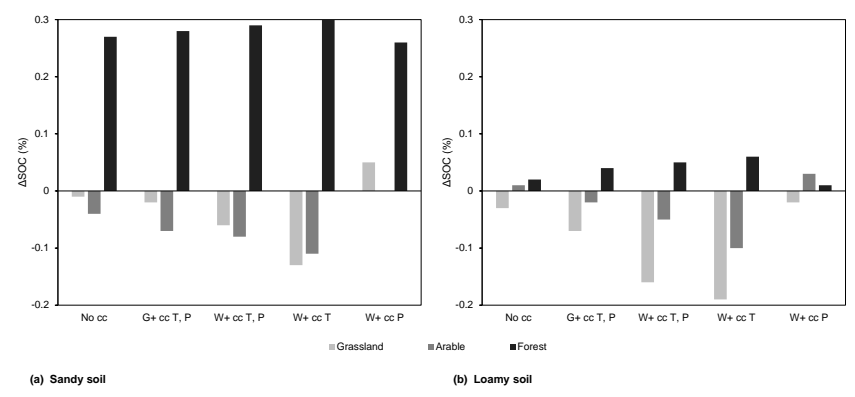

Figure 4. Actual changes in SOC contents $(0-20 \mathrm{~cm})$ between 2013 and $2100 \mathrm{~s}$ in grassland systems, arable land systems, and forest systems under the various climate change scenario $(T$ : temperature; $P$ : precipitation; No cc: no-climate-change scenario; $\mathrm{G}+$ cc $T, P$ : G+ climate change scenario considering changes in both $T$ and $P$; $\mathrm{W}+$ cc $T, P: \mathrm{W}+$ climate change scenario considering changes in both $T$ and $P ; \mathrm{W}+$ cc $T: \mathrm{W}+$ climate change scenario considering changes only in $T ; \mathrm{W}+$ cc $P: \mathrm{W}+$ climate change scenario considering changes only in $P$ ) in the (a) sandy soil and (b) loamy soil.

ulation period (2013-2100), the model predicted SOC losses for the agricultural systems and SOC gains for the forest systems. With two exceptions (the sandy arable land system and the sandy forest system), the model results for the no-climate-change scenario (No cc) show rather steady SOC levels. Apparently, the invariable climate and land management under this scenario results in equilibrium conditions for the SOC levels. The radical reduction in manure application in the sandy arable land system around 1900 causes a continued decrease in SOC stocks under the no-climate-change scenario for this system. In contrast, in the sandy forest system, the land use change from heathland to forest around 1900 contributes to a considerable and stable increase in SOC levels, which is expected to persist for decades to come. This suggests that, in contrast to what Senapati et al. (2013) found for relatively undisturbed land use systems, initialization of SOC pools is essential for systems that have undergone major changes in land use.

For the agricultural systems, the future projections for total SOC stocks under the two climate change scenarios $(\mathrm{G}+$ cc $T, P$ and $\mathrm{W}+$ cc $T, P$ ) show losses of nearly $5 \%$ for the period 2013-2100. The losses are higher for the more extreme scenario ( $\mathrm{W}+\mathrm{cc} T, P$ ). Compared to the no-climatechange scenario (No cc), the losses amount to nearly $4 \%$ for the grassland systems and $2 \%$ for the arable land systems. Opposite results are projected for the forest systems, for which the climate change scenarios $(\mathrm{G}+\mathrm{cc} T, P$ and $\mathrm{W}+\operatorname{cc} T, P$ ) result in an increase in total SOC levels of approximately $8 \%$ for the period 2013-2100, with slightly higher total SOC gains for the $\mathrm{W}+$ scenario. Compared to the no-climate-change scenario (No cc), the gains amount to approximately $2 \%$.

The analysis of the sole effects of changes in temperature and changes in precipitation reveals contrasting behaviour

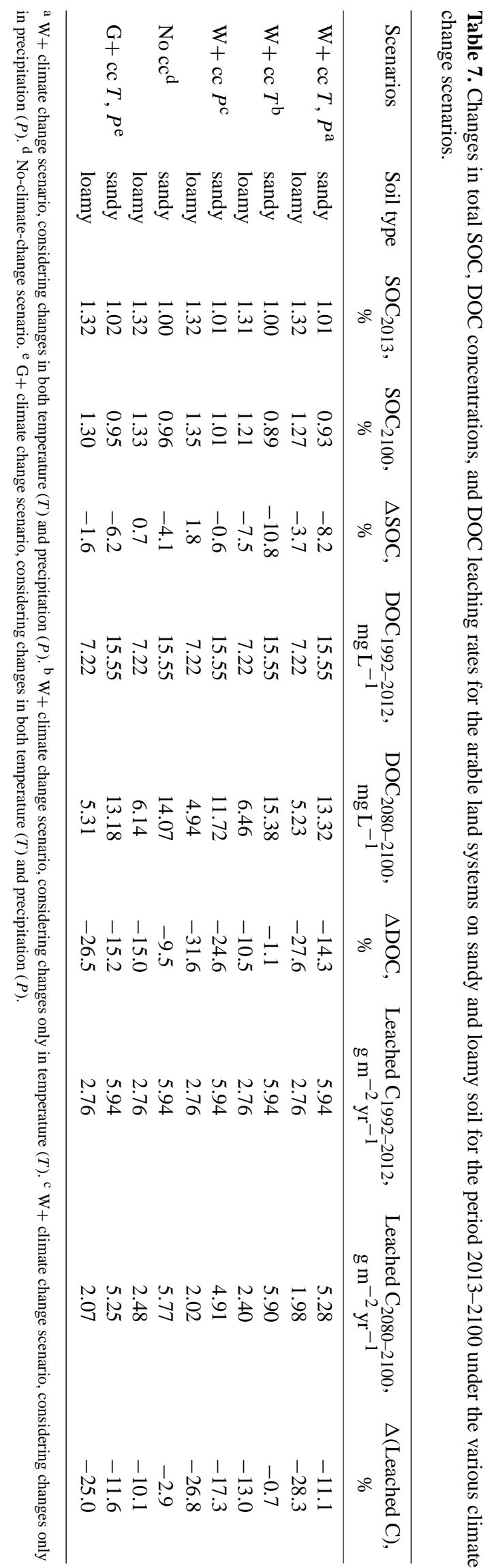

www.biogeosciences.net/13/1519/2016/ 
for the several systems. The analysis of the individual effect of temperature on the future development of SOC dynamics (W+ cc $T$ scenario) shows that, for all systems, elevated temperature has a positive effect on both carbon inputs via primary production and decomposition by soil biota (Tables S2S4 in the Supplement). However, the net effect of more carbon entering the soil and of accelerated SOC decomposition differs between the systems. In the forest systems, the increased SOC levels under the $\mathrm{W}+\mathrm{cc} T$ scenario in comparison to the no-climate-change scenario (No cc) indicates that the positive effect of temperature on carbon inputs is greater than that on decomposition. In agricultural systems, however, the SOC levels under the $\mathrm{W}+\mathrm{cc} T$ scenario decrease in comparison to the no-climate-change scenario. In these systems, removal of biomass by harvest or grazing subdues the effect of increased carbon inputs, which, under an increase in decomposition rates, causes a net decrease in SOC levels under increasing temperature.

Results from the simulations addressing the effect of changes only in precipitation (W+ cc $P$ scenario) indicate that drier climate conditions in comparison to the no-climatechange scenario has an overall negative effect on both SOC decomposition and carbon inputs. The antagonistic effect of decreased primary production and hindered decomposition causes lower SOC levels in the forest system compared to the no-climate-change scenario (No cc). As for the agricultural systems under the $\mathrm{W}+\mathrm{cc} T$ scenario, the effects on primary production are attenuated by harvest and grazing, which cause higher SOC levels in the agricultural systems compared to the no-climate-change scenario. Thus, the effects of changes in precipitation are opposite to the effects on temperature, but the effect of temperature predominated over that of precipitation.

The climate change scenarios for the period 2013-2100 result in a decrease in DOC concentrations and leaching rates for all systems, except for the $\mathrm{W}+\mathrm{cc} T$ for the forest systems (Tables 6-8). The decrease in DOC leaching rates is more pronounced for the loamy soils, in which SOC is absorbed more effectively to soil minerals. Under the noclimate-change scenario (No cc), the model predicted a decline in DOC concentrations for all systems and in DOC leaching rates for all systems except for the sandy forest system. For this system, the DOC leaching rate shows a slight upward trend during the period 2013-2100.

The scenario considering the sole effect of changes in temperature (W+ cc $T$ ) (Tables 6-8) shows a decrease in leached carbon rates for all cases except for the forest system on sandy soil. For this system, the warmer weather conditions lead to increased leached carbon fluxes and DOC concentrations for the period 2013-2100. For the forest system on loamy soil, the model predictions show a decrease in DOC leaching rates and an increase in DOC concentrations due to a decrease in the water flux through the soil profile at the end of the simulation period. The simulated changes (positive and negative) are comparable to the values resulting from the no- climate-change scenario (No cc), suggesting that temperature only plays a subordinate role in dissolved organic carbon dynamics. Projected changes in precipitation rates $(\mathrm{W}+\mathrm{cc} P$ scenario) cause a considerable decrease in DOC concentrations and leaching rates in all systems (Tables 6-8), confirming that drier soil conditions during summer, when DOC is larger than during winter due to larger biological activity and decomposition rates, constrain the leaching of organic material from the soil profile.

The future SOC predictions that we present in this paper are in accordance with previous studies that confirmed negative interactions between temperature and SOC levels and positive interactions between precipitation and SOC levels (Jenny, 1941, 1980; Parton et al., 1987; Burke et al., 1989; Schimel et al., 1994; Kirschbaum, 2000; Smith et al., 2005; Gottschalk et al., 2012). Our projected increases of SOC levels in forest systems under the climate change scenarios is in agreement with previous studies, but the magnitude of the projected changes varies. Liski et al. (2002) estimated that the total SOC stocks in European forest soils will increase by about $40 \%$ between 1990 and 2040, whereas Smith et al. (2006) projected an increase of only 3.1 to $4.1 \%$. For grasslands, Smith et al. (2005) predicted a slight decrease by $1 \%$ or even a slight increase $1.6 \%$ in SOC levels for European grasslands between 1990 and 2080, which are much smaller changes than our results indicate. These smaller or even opposite changes in grassland SOC levels can be attributed to a much more enhanced effect of the increase in net primary production and the associated increased organic carbon inputs to grassland soil in the model employed by Smith et al. (2005). In line with our findings, Smith et al. (2005) found that as a result of climate change, SOC contents in European croplands are expected to decrease by 2.8 to $4.4 \%$ in 2080 compared to 1990 . Post et al. (2008) also projected an overall SOC decline in arable soils in the Elbe River basin by $4.5 \%$ between 1990 and 2050 due to climate change. This effect greatly reduced the SOC losses due to direct impacts of climate change on the soil.

A study on the impact of climate change on SOC in agricultural soils in the Mediterranean climate zone (ÁlvaroFuentes et al., 2012a) showed opposite trends compared to our findings. Their study projected SOC gains by 4.5 to $10 \%$ in northeastern Spain by the end of the 21 st century due to temperature-induced increase in carbon inputs and precipitation-induced constraints in soil microbial activity. In contrast to our conclusion that the effect of temperature predominates over that of precipitation, Álvaro-Fuentes et al. (2012a) concluded that soil moisture was the main controlling factor of SOC sequestration in Spanish soils.

In concordance with our findings, Harrison et al. (2008) concluded that DOC release in various soil types in the United Kingdom was mainly controlled by precipitation, but it was also to a smaller extent affected by temperature through a decrease in soil water leaching (enhanced evaporation). Tranvik et al. (2002) also indicated the importance 


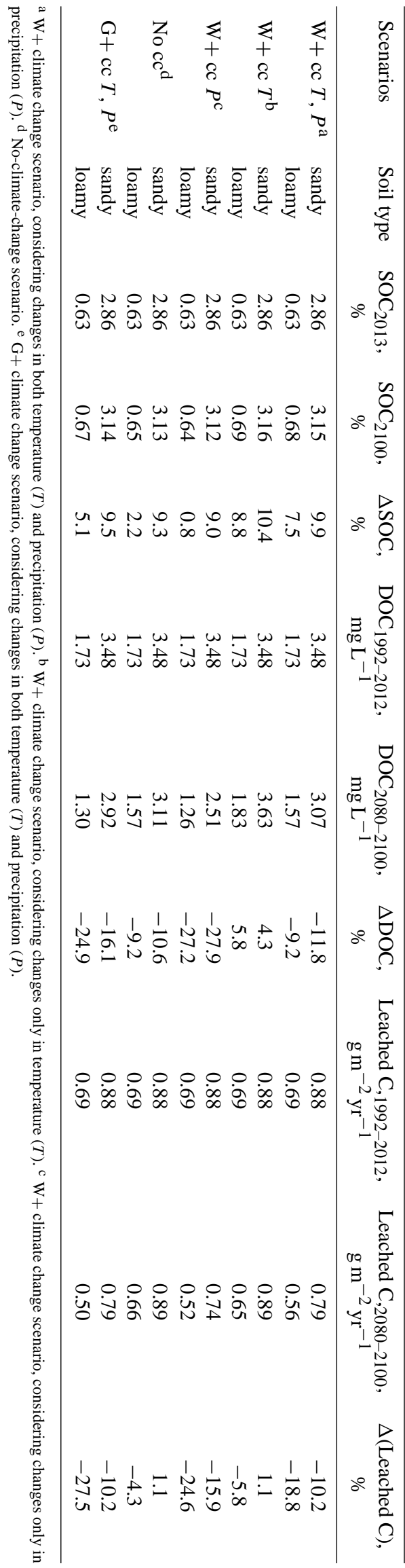

of changes in precipitation due to climate change on DOC leaching.

\subsubsection{Land management change scenario}

The projected changes in SOC levels under the land management scenarios $(\mathrm{G}+\mathrm{cc} \mathrm{RF}$ and $\mathrm{W}+\mathrm{cc} \mathrm{RF})$ vary between the agricultural systems. For the grassland systems (Table 9), the simulated reduction in nitrogen and phosphorus applied via mineral fertilisers (by 60 and $100 \%$ respectively) and in phosphorus applied via manure (by $20 \%$ ) has a negligible effect on SOC stocks and DOC leaching. This negligible response of SOC to decreased fertilisation rates in the grassland systems can be explained by the vast amounts of organic carbon added to these systems via manure throughout the simulation period (almost $3 \mathrm{tha}^{-1} \mathrm{yr}^{-1}$ ), which overwhelmed the effect of changes in the application rates of nutrients via mineral fertilisers.

For the arable land systems (Table 10), a reduction in nitrogen and phosphorus applied via mineral fertilisers (by nearly 20 and $80 \%$ respectively) and in phosphorus applied via manure (by $20 \%$ ) results in a decline in SOC by approximately $11 \%$ and in DOC leaching rates and concentrations by approximately $15 \%$, in comparison to the model results for climate change effects alone $(\mathrm{W}+\mathrm{cc} T, P$ and $\mathrm{G}+\mathrm{cc} T, P$ scenarios). Organic carbon addition via manure in arable land systems is much lower than in the grassland systems and is probably not sufficient to outweigh the effects of a reduction in nutrients applied via mineral fertilisers.

Similar findings for SOC have been reported by Lugato et al. (2007), who validated the Century model against observed data of SOC contents in arable land under different fertilisation treatments, including the use of manure and artificial fertilisers. Their results suggest that SOC differences among the systems could be mainly attributed to changes in carbon inputs via manure, which is added in amounts much higher than mineral fertilisers. The results of experimental studies by Ghani et al. (2006), Ruark et al. (2009), and Walmsley et al. (2011) support our finding that nitrogen fertilisation rates have no major influence on DOC leaching from soil in various agroecosystems.

Thus, the effect of changes in land management on the decline in SOC levels and DOC leaching rates in arable land systems is greater than the effect of climate change. This implies that measures to mitigate SOC decline due to climate change and reduced fertiliser gifts and to increase SOC sequestration in these systems should likely be sought in other land management options, such as reduced or no tillage, flexible drainage, or changing crop rotation (e.g. West and Post, 2002; Olson et al., 2014). 


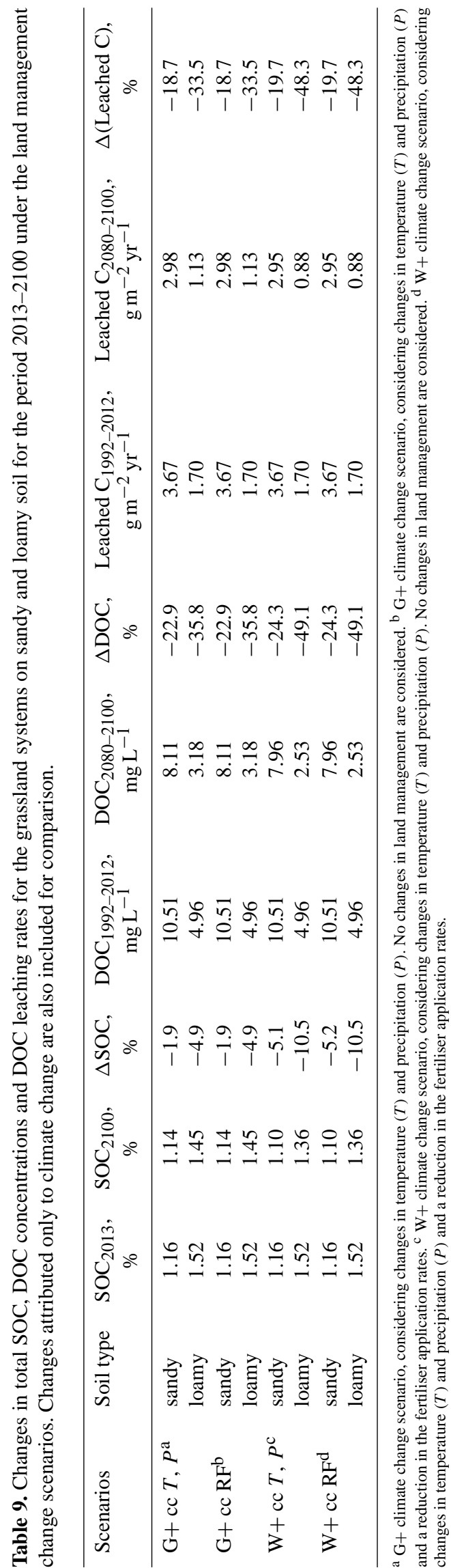

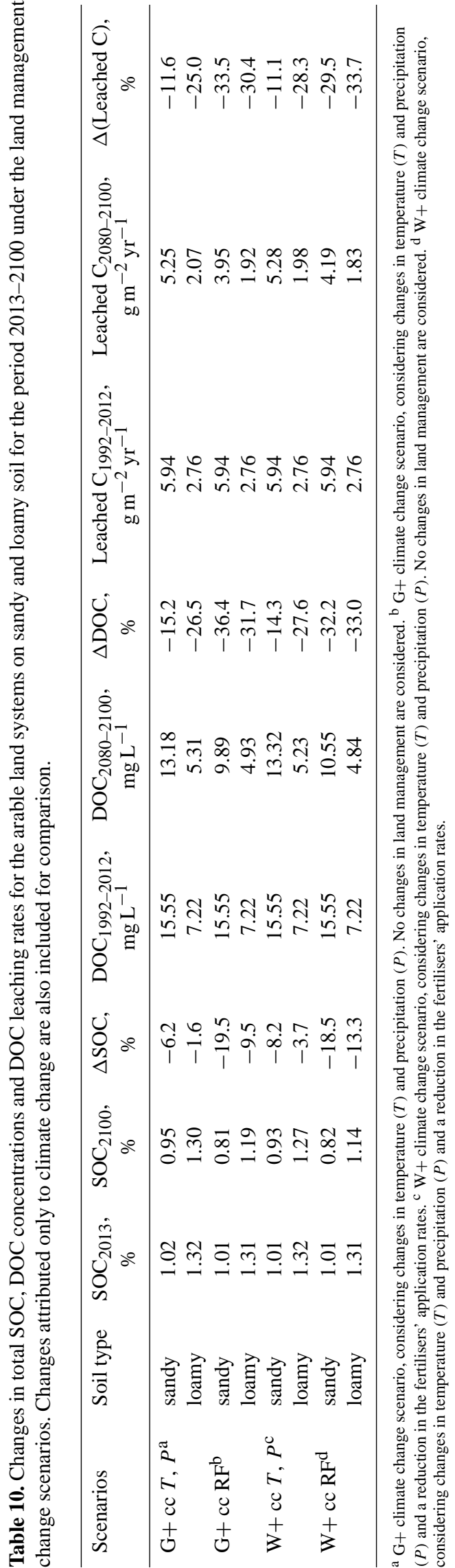

Biogeosciences, 13, 1519-1536, 2016 


\section{Conclusions}

In this modelling study, we adopted the Century model to simulate the development of SOC and DOC for typical northwestern European conditions under various scenarios of climate change and land management practices. To our knowledge, this is the first time that the Century model has been applied to assess the effects of climate change and land management on DOC concentrations and leaching rates. The highest current SOC levels were simulated for the forest system on sandy soil $(2.86 \%)$. SOC levels of the grassland systems (1.16 and $1.52 \%$ on sandy soil and loamy soil respectively) were higher than those of the arable land systems (1.02 and $1.32 \%$ on sandy soil and loamy soil respectively), whereas the lowest SOC levels were predicted for the forest system on loamy soil $(0.63 \%)$. In general, these simulated SOC levels were within or close to the measured ranges.

For the period 2013-2100, we project a decrease in SOC by 2 to $10 \%$ in agricultural systems and a slight increase in SOC by 5 to $10 \%$ in forest systems, under the two climate change scenarios considered $(\mathrm{G}+\mathrm{cc} T, P$ and $\mathrm{W}+\mathrm{cc} T$, $P)$. For all systems, the DOC concentrations and leaching rates will decrease by up to $50 \%$. We found that an increase in temperature causes an increase in both carbon inputs via primary production and in carbon losses via enhanced decomposition. Changes in only precipitation have an opposite effect on carbon inputs and decomposition compared to the effect of temperature. In the agricultural systems, the effects of temperature and precipitation on carbon inputs are attenuated by harvest and grazing. For SOC, the temperature effect predominates over the precipitation effect for all systems, whereas for the DOC leaching rates the precipitation effect is more dominant. Our results show that a reduction in fertiliser application rates under the land management change scenario will lead to negligible changes in SOC and DOC leaching rates for the grassland systems compared to the climate change scenarios and to an additional decrease in SOC levels and DOC leaching rates for the arable land systems. These effects of changes in land management on the decline in SOC levels and DOC leaching rates in arable land systems are greater than the effect of climate change.

The Century model proved to be a useful tool for modelling past, present, and future SOC contents and DOC concentrations, thus providing essential information for assessing the effects of climate change and land management on carbon sequestration in soils and the associated implications for soil contaminant transport.

The Supplement related to this article is available online at doi:10.5194/bg-13-1519-2016-supplement.
Author contributions. Maria Stergiadi, M. van der Perk, Ton C. M. de Nijs, and Marc F. P. Bierkens designed the modelling procedure. Maria Stergiadi performed the model simulations. Maria Stergiadi prepared the manuscript with contributions from all co-authors. Marcel van der Perk performed the final editing of the manuscript.

Acknowledgements. This research was conducted in the framework of the "Climate Cascades" Project, funded by the Dutch National Institute for Public Health and the Environment (RIVM), in collaboration with Utrecht University (The Netherlands), AlterraWageningen University (The Netherlands), and VITO (Belgium). The authors would like to thank Oene Oenema for his valuable advice on the Century model parameterization with respect to land management, Luc Bonten (Alterra-Wageningen University) for providing soil data, and Cindy Keough (Colorado State University, USA), Peter de Willigen, Hanneke Heesmans (Alterra-Wageningen University), and Christian Mulder (RIVM) for advice on modelling. We thank the two anonymous reviewers for their constructive comments to the discussion paper, which greatly helped to improve the manuscript.

Edited by: J.-A. Subke

\section{References}

Adams, A. B., Harrison, R. B., Sletten, R. S., Strahm, B. D., Turnblom, E. C., and Jensen, C. M.: Nitrogen-fertilization impacts on carbon sequestration and flux in managed coastal Douglas-fir stands of the Pacific Northwest, Forest Ecol. Manag., 220, 313325, doi:10.1016/j.foreco.2005.08.018, 2005.

Alterra: Recommendations for establishing Action Programmes under Directive 91/676/EEC concerning the protection of waters against pollution caused by nitrates from agricultural sources, Final Report, Contract number No. 07, 0307/2010/580551/ETU/B1, Alterra-Wageningen University and Research Centre, Wageningen, the Netherlands, 2011.

Alvarez, R.: A review of nitrogen fertilizer and conservation tillage effects on soil organic carbon storage, Soil Use Manage., 21, 38 52, doi:10.1111/j.1475-2743.2005.tb00105.x, 2005.

Álvaro-Fuentes, J., Easter, M., and Paustian, K.: Climate change effects on organic carbon storage in agricultural soils of northeastern Spain, Agr. Ecosyst. Environ., 155, 87-94, doi:10.1016/j.agee.2012.04.001, 2012a.

Álvaro-Fuentes, J., Morell, F. J., Plaza-Bonilla, D., Arrue, J. L., and Cantero-Martinez, C.: Modelling tillage and nitrogen fertilization effects on soil organic carbon dynamics, Soil Till. Res., 120 , 32-39, doi:10.1016/j.still.2012.01.009, 2012b.

Baldock, J. A.: Composition and cycling of organic carbon in soil, in: Nutrient Cycling in Terrestrial Ecosystems, Soil Biology Series, vol. 10, edited by: Marschner, P. and Rengel, Z., SpringerVerlag, Berlin, 1-35, 2007.

Bodemdata: Soil Database, http://maps.bodemdata.nl/bodemdatanl/ index.jsp, last access: 5 January 2014 (in Dutch).

Bouman, M. T. I. J., Bos, J. A. A., and Van Beek, R.: Van wildernis naar cultuurlandschap. Een reconstructie van de regionale 
vegetatieontwikkeling van Twente in het Holoceen, ADC ArchaeoProjecten rapport 3413, ADC ArchaeoProjecten, Amersfoort, 2013 (in Dutch).

Braakhekke, M. C., Wutzler, T., Beer, C., Kattge, J., Schrumpf, M., Ahrens, B., Schöning, I., Hoosbeek, M. R., Kruijt, B., Kabat, P., and Reichstein, M.: Modeling the vertical soil organic matter profile using Bayesian parameter estimation, Biogeosciences, 10, 399-420, doi:10.5194/bg-10-399-2013, 2013.

Brandsma, T. and Buishand, T. A.: KNMI contribution to the European project POPSICLE, Technical report TR-194, KNMI, De Bilt, the Netherlands, 1996.

Burke, I. C., Yonker, C. M., Parton, W. J., Cole, C. V., Flach, K., and Schimel, D. S.: Texture, climate and cultivation effects on soil organic matter in US grassland soils, Soil Sci. Soc. Am. J., 53, 800-805, doi:10.2136/sssaj1989.03615995005300030029x, 1989.

Burke, I. C., Elliott, E. T., and Cole, C. V.: Influence of microclimate, landscape position, and management on soil organic matter in agroecosystems, Ecol. Appl., 5, 124-131, doi:10.2307/1942057, 1995.

Capriel, P.: Trends in organic carbon and nitrogen contents in agricultural soils in Bavaria (south Germany) between 1986 and 2007, Eur. J. Soil Sci., 64, 445-454, doi:10.1111/ejss.12054, 2013.

Centraal Bureau voor de Statistiek (CBS): Compendium voor de Leefomgeving, http://www.compendiumvoordeleefomgeving.nl, last access: 7 January 2014a (in Dutch).

Centraal Bureau voor de Statistiek (CBS): Statline Database, http: //statline.cbs.nl, last access: 7 January 2014b (in Dutch).

Christensen, O. B., Goodess, C. M., Harris, I., and Watkiss, P.: European and global climate change projections: discussion of climate change model outputs, scenarios and uncertainty in the EC RTD ClimateCost Project, in: The ClimateCost Project, Final report, vol. 1, edited by: Watkiss, P., Stockholm Environment Institute, Sweden, 2011.

Commission of the European Communities: Council Directive concerning the protection of waters against pollution caused by nitrates from agricultural sources, 91/676/EEC, European Economic Community, Brussels, 1991.

Conant, R. T., Drijber, R. A., Haddix, M. L., Parton, W. J., Paul, E. A., Plante, A. F., Six, J., and Steinweg, J. M.: Sensitivity of organic matter decomposition to warming varies with its quality, Glob. Change Biol., 14, 868-877, doi:10.1111/j.13652486.2008.01541.x, 2008.

Cramer, W., Bondeau, A., Woodward, F. I., Prentice, I. C., Betts, R. A., Brovkin, V., Cox, P. M., Fisher, V., Foley, J. A., Friend, A. D., Kucharik, C., Lomas, M. R., Ramankutty, N., Sitch, S., Smith, B., White, A., and Young-Molling, C.: Global response of terrestrial ecosystem structure and function to $\mathrm{CO}_{2}$ and climate change: results from six dynamic global vegetation models, Glob. Change Biol., 7, 357-373, doi:10.1046/j.13652486.2001.00383.x, 2001.

Davidson, E. A. and Janssens, I. A.: Temperature sensitivity of soil carbon decomposition and feedbacks to climate change, Nature, 440, 165-173, doi:10.1038/nature04514, 2006.

De Bakker, H.: Major soils and soil regions in the Netherlands, Junk-The Hague, Boston, London/Pudoc, Wageningen, the Netherlands, 1979.
De Walle, F. B. and Sevenster, J.: Agriculture and the Environment: Minerals, Manure and Measures, Kluwer, Dordrecht, 211 pp., 1998.

Dijkstra, J. J., Meeussen, J. C. L., and Comans, R. N. J.: Leaching of heavy metals from contaminated soils: an experimental and modeling study, Environ. Sci. Technol., 38, 4390-4395, doi:10.1021/es049885v, 2004.

Don, A., Schumacher, J., Scherer-Lorenzen, M., Scholten, T., and Schulze, E.-D.: Spatial and vertical variation of soil carbon at two grassland sites - Implications for measuring soil carbon stocks, Geoderma, 141, 272-282, doi:10.1016/j.geoderma.2007.06.003, 2007.

Driscoll, C. T., Fuller, R. D., and Simone, D. M.: Longitudinal variations in trace metal concentrations in a northern forested ecosystem, J. Environ. Qual., 17, 101-107, doi:10.2134/jeq1988.00472425001700010015x, 1988.

Elliott, H. A., Liberati, M. R., and Huang, C. P.: Competitive adsorption of heavy metals by soils, J. Environ. Qual., 15, 214-219, doi:10.2134/jeq1986.00472425001500030002x, 1986.

Ghani, A., Dexter, M., Kear, M., Lindsey, S., and Ledgard, S. L.: Influence of plant litter and animal excreta on leaching of dissolved organic nitrogen and carbon in pastoral soil, in: Proceedings of the 18th World Congress of Soil Science, Philadelphia, USA, 915 July 2006, Dunmore Printing Company, Palmerston, 1762 pp., 2006.

Glendining, M. J. and Powlson, D. S.: The effect of long-term applications of inorganic nitrogen fertilizer on soil organic nitrogen, in: Advances in Soil Organic Matter Research: The Impact on Agriculture and the Environment, edited by: Wilson, W. S., The Royal Society of Chemistry, Cambridge, 329-338, 1991.

Gottschalk, P., Smith, J. U., Wattenbach, M., Bellarby, J., Stehfest, E., Arnell, N., Osborn, T. J., Jones, C., and Smith, P.: How will organic carbon stocks in mineral soils evolve under future climate? Global projections using RothC for a range of climate change scenarios, Biogeosciences, 9, 3151-3171, doi:10.5194/bg-9-3151-2012, 2012.

Groenenberg, J. E., Dijkstra, J. J., Bonten, L. T. C., De Vries, W., and Comans, R. N. J.: Evaluation of the performance and limitations of empirical partition-relations and process based multisurface models to predict trace element solubility in soils, Environ. Pollut., 166, 98-107, doi:10.1016/j.envpol.2012.03.011, 2012.

Guisquiani, P. L., Concezzi, L., Businelli, M., and Macchioni, A.: Fate of pig sludge liquid fraction in calcareous soil: agricultural and environmental implications, J. Environ. Qual., 27, 364-371, doi:10.2134/jeq1998.00472425002700020017x, 1998.

Hanegraaf, M. C., Hoffland, E., Kuikman, P. J., and Brussaard, L.: Trends in soil organic matter contents in Dutch grasslands and maize fields on sandy soils, Eur. J. Soil Sci., 60, 213-222, doi:10.1111/j.1365-2389.2008.01115.x, 2009.

Harrison, A. F., Taylor, K., Scott, A., Poskitt, J., Benham, D., Grace, J., Chaplow, J., and Rowland, P.: Potential effects of climate change on DOC release from three different soil types on the Northern Pennines UK: examination using field manipulation experiments, Glob. Change Biol., 14, 687-702, doi:10.1111/j.1365-2486.2007.01504.x, 2008.

Heikkinen, J., Ketoja, E., Nuutinen, V., and Regina, K.: Declining trend of carbon in Finnish cropland soils in 1974-2009, Glob. Change Biol., 19, 1456-1469, doi:10.1111/gcb.12137, 2013. 
Impellitteri, C. A., Lu, Y. F., Saxe, J. K., Allen, H. E., and Peijnenburg, W.: Correlation of the partitioning of dissolved organic matter fractions with the desorption of $\mathrm{Cd}, \mathrm{Cu}, \mathrm{Ni}$, $\mathrm{Pb}$ and $\mathrm{Zn}$ from 18 Dutch soils, Environ. Int., 28, 401-410, doi:10.1016/S0160-4120(02)00065-X, 2002.

IPCC: Climate Change 2007: The Physical Science Basis, in: Contribution of Working Group I to the Fourth Assessment Report of the Intergovernmental Panel on Climate Change, edited by: Solomon, S., Qin, D., Manning, M., Chen, Z., Marquis, M., Averyt, K. B., Tignor, M., and Miller, H. L., Cambridge University Press, Cambridge, United Kingdom and New York, New York, 996 pp., 2007.

Jenny, H.: Factors of Soil Formation: A System of Quantitative Pedology, McGraw-Hill Book Co, New York, 1941.

Jenny, H.: The Soil Resource: Origin and Behavior, SpringerVerlag, New York, 377 pp., 1980.

Kaplan, J. O., Krumhardt, K. M., and Zimmermann, N.: The prehistoric and preindustrial deforestation of Europe, Quaternary Sci. Rev., 28, 3016-3034, doi:10.1016/j.quascirev.2009.09.028, 2009.

Khan, S. A., Mulvaney, R. L., Ellsworth, T. R., and Boast, C. W.: The myth of nitrogen fertilization for soil carbon sequestration, J. Environ. Qual., 36, 1821-1832, doi:10.2134/jeq2007.0099, 2007.

Kindler, R., Siemens, J., Kaiser, K., Walmsley, D. C., Bernhofer, C., Buchmann, N., Cellier, P., Eugster, W., Gleixner, G., Grünwald, T., Heim, A., Ibrom, A., Jones, S. K., Jones, M., Klumpp, K., Kutsch, W., Steenberg Larsen, K., Lehuger, S., Loubet, B., Mckenzie, R., Moors, E., Osborne, B., Pilegaard, K., Rebmann, C., Saunders, M., Schmidt, M. W. I., Schrumpf, M., Seyfferth, J., Skiba, U., Soussana, J.-F., Sutton, M. A., Tefs, C., Vowinckel, B., Zeeman, M. J., and Kaupenjohann, M.: Dissolved carbon leaching from soil is a crucial component of the net ecosystem carbon balance, Glob. Change Biol., 17, 1167-1185, doi:10.1111/j.1365-2486.2010.02282.x, 2011.

Kirschbaum, M. U. F.: Will changes in soil organic carbon act as a positive or negative feedback on global warming, Biogeochemistry, 48, 21-51, doi:10.1023/A:1006238902976, 2000.

Knibbe, M. T.: Feed, fertilizer and agricultural productivity in the Netherlands, 1880-1930, Agr. Hist., 74, 39-57, 2000.

KNMI: Klimaat in de 21e eeuw, vier scenario's voor Nederlands, Royal Dutch Meteorological Institute, De Bilt, the Netherlands, 2006 (in Dutch).

KNMI: Klimaatverandering in Nederland, aanvulling op de KNMI'06 scenario's, Royal Dutch Meteorological Institute, De Bilt, the Netherlands, 2009 (in Dutch).

Lal, R.: Agricultural activities and the global carbon cycle, Nutr. Cycl. Agroecosys., 70, 103-116, doi:10.1023/B:FRES.0000048480.24274.0f, 2004.

Lenderink, G., Van Ulden, A., Van den Hurk, B., and Keller, F., A study on combining global and regional climate model results for generating climate scenarios of temperature and precipitation for the Netherlands, Clim. Dynam., 29, 157-176, doi:10.1007/s00382-007-0227-z, 2007.

Liski, J., Perruchoud, D., and Karjalainen, T.: Increasing carbon stocks in the forest soils of western Europe, Forest Ecol. Manag., 169, 159-175, doi:10.1016/S0378-1127(02)00306-7, 2002.

LTO: Koersvast richting 2020: voortvarend in verantwoordelijkheid, Plan Bedrijfsleven Agroketen Veehouderij en Milieu,
Land- en Tuinbouw Organisatie, The Hague, the Netherlands, 2013 (in Dutch).

Lugato, E., Paustian, K., and Giardini, L.: Modelling soil organic carbon dynamics in two long-term experiments of north-eastern Italy, Agr. Ecosyst. Environ., 120, 423-432, doi:10.1016/j.agee.2006.11.006, 2007.

Meersmans, J., Van Wesemael, B., De Ridder, F., Dotti, M.F., De Baets, S., and Van Molle, M.: Changes in organic carbon distribution with depth in agricultural soils in northern Belgium, 1960-2006, Glob. Change Biol., 15, 2739-2750, doi:10.1111/j.1365-2486.2009.01855.x, 2009.

Metherell, A. K., Harding, L. A., Cole, C. V., and Parton, W. J.: Century Soil Organic Matter Model Environment Technical Documentation, Agroecosystem Version 4.0, Great Plains System Research Unit Technical Report No. 4, USDA-ARS, Fort Collins, Colorado, USA, 245 pp., 1993.

Metherell, A. K., Cambardella, C. A., Parton, W. J., Peterson, G. A., Harding, L. A., and Cole, C. V.: Simulation of soil organic matter dynamics in dryland wheat-fallow cropping systems, in: Soil Management and Greenhouse Effect, edited by: Lal, R., Kimball, J., Levine, E., and Stewart, B. A., CRC Press, Boca Raton, Florida, USA, 259-270, 1995.

Michalzik, B., Kalbitz, K., Park, J.-H., Solinger, S., and Matzner, E.: Fluxes and concentrations of dissolved organic carbon and nitrogen - a synthesis for temperate forests, Biogeochemistry, 52, 173-205, doi:10.1023/A:1006441620810, 2001.

Ministry of Economic Affairs, Agriculture and Innovation: Mestbeleid 2010-2013: tabellen, Tabel 1 Stikstofgebruiksnormen, Ministry of Economic Affairs, Agriculture and Innovation, The Hague, the Netherlands, 2011 (in Dutch).

Olson, K. R., Al-Kaisi, M., Lal, R., and Lowery, B.: Examining the paired comparison method approach for determining soil organic carbon sequestration rates, J. Soil Water Conserv., 69, 193A197A, doi:10.2489/jswc.69.6.193A, 2014.

Parton, W. J., Schimel, D. S., Cole, C. V., and Ojima, D. S.: Analysis of factors controlling soil organic matter levels in Great Plains grasslands, Soil Sci. Soc. Am. J., 51, 1173-1179, doi:10.2136/sssaj1987.03615995005100050015x, 1987.

Parton, W. J., Stewart, J. W. B., and Cole, C. V.: Dynamics of C, N, P and S in grassland soils: a model, Biogeochemistry, 5, 109131, doi:10.1007/BF02180320, 1988.

Parton, W. J., Scurlock, J. M. O., Ojima, D. S., Gilmanov, T. G., Scholes, R. J., Schimel, D. S., Kirchner, T., Menaut, J.-C., Seastedt, T., Garcia Moya, E., Kamnalrut, A., and Kinyamario, J. I.: Observations and modeling of biomass and soil organic matter dynamics for the grassland biome worldwide, Global Biogeochem. Cy., 7, 785-809, doi:10.1029/93gb02042, 1993.

Paul, E. A.: Dynamics of organic matter in soils, Plant Soil, 76, 275-285, 1984.

Paustian, K., Parton, W. J., and Persson, J.: Modeling soil organic matter in organic amended and nitrogen-fertilized long-term plots, Soil Sci. Soc. Am. J., 56, 476-488, doi:10.2136/sssaj1992.03615995005600020023x, 1992.

Paustian, K., Elliott, E. T., Peterson, G. A., and Killian, K.: Modelling climate, $\mathrm{CO}_{2}$ and management impacts on soil carbon in semi-arid agroecosystems, Plant Soil, 187, 351-365, doi:10.1007/BF00017100, 1996.

Paustian, K., Andren, O., Janzen, H., Lal, R., Smith, P., Tian, G., Tiessen, H., Van Noordwijk, M., and Woomer, P.: Agricultural 
soil as a $\mathrm{C}$ sink to offset $\mathrm{CO}_{2}$ emissions, Soil Use Manage, 13, 230-244, 1997a.

Paustian, K., Collins, H. P., and Paul, E. A.: Management controls on soil carbon, in: Soil Organic Matter in Temperate Agroecosystems: Long-term Experiments in North America, edited by: Paul, E. A., Paustian, K. H., Elliott, E. T., and Cole, C. V., Lewis Publishers, CRC Press, Boca Raton, Florida, USA, 15-49, 1997b.

Post, J., Conradt, T., Suckow, F., Krysanova, V., Wechsung, F., and Hattermann, F. F.: Integrated assessment of cropland soil carbon sensitivity to recent and future climate in the Elbe River basin, Hydrolog. Sci. J., 53, 1043-1058, doi:10.1623/hysj.53.5.1043, 2008.

Post, W. M., Izaurralde, R. C., Mann, L. K., and Bliss, N.: Monitoring and verifying soil organic carbon sequestration, in: Proceedings of the St. Michaels Workshop on Carbon Sequestration in Soils: Science, Monitoring and Beyond, edited by: Rosenberg, N., Izaurralde, R., and Malone, E., 3-5 December 1998, Battelle Press, Columbus, USA, 41-66, 1999.

Province of Noord-Brabant: Provincial Soil Quality Monitoring Network, 1995-1996, Noord-Brabant, the Netherlands, 1996.

Reeves, D. W.: The role of organic matter in maintaining soil quality in continuous cropping systems, Soil Till. Res., 43, 131-167, doi:10.1016/S0167-1987(97)00038-X, 1997.

Reid, K.: Comment on the myth of nitrogen fertilization for soil carbon sequestration, J. Environ. Qual., 37, 739-740, doi:10.2134/jeq2008.0001le, 2008.

Reijneveld, A., Van Wensem, J., and Oenema, O.: Soil organic carbon contents of agricultural land in the Netherlands between 1984 and 2004, Geoderma, 152, 231-238, doi:10.1016/j.geoderma.2009.06.007, 2009.

Riley, H. and Bakkegard, M.: Declines of soil organic matter content under arable cropping in southeast Norway, Acta Agr. Scand. B-S. P., 56, 217-223, doi:10.1080/09064710510029141, 2006.

RIVM: Database of the Biological Indicator of Soil Quality (BISQ), National Institute for Public Health and the Environment, Bilthoven, the Netherlands, 2014.

Römkens, P., Hoenderboom, G., and Dolfing, J.: Copper solution geochemistry in arable soils: Field observations and model application, J. Environ. Qual., 28, 776-783, doi:10.2134/jeq1999.00472425002800030007x, 1999.

Römkens, P. F. A. M., Groenenberg, J. E., Bonten, L. T. C., De Vries, W., and Bril, J.: Derivation of partition relationships to calculate $\mathrm{Cd}, \mathrm{Cu}, \mathrm{Ni}, \mathrm{Pb}$ and $\mathrm{Zn}$ solubility and activity in soil solutions, Alterra Report no. 305, Alterra, Wageningen, 2004.

Ruark, M. D., Brouder, S. M., and Turco, R. F.: Dissolved organic carbon losses from tile drained agroecosystems, J. Environ. Qual., 38, 1205-1215, doi:10.2134/jeq2008.0121, 2009.

Sauvé, S., Hendershot, W., and Allen, H. E.: Solid-solution partitioning of metals in contaminated soils: dependence on $\mathrm{pH}$, total metal burden, and organic matter, Environ. Sci. Technol., 34, 1125-1131, doi:10.1021/es9907764, 2000.

Schijven, J. F. and De Roda Husman, A. M.: Effect of climate changes on waterborne disease in the Netherlands, Water Sci. Technol., 51, 79-87, 2005.

Schimel, D. S.: Terrestrial ecosystems and the carbon cycle, Glob. Change Biol., 1, 77-91, doi:10.1111/j.13652486.1995.tb00008.x, 1995.

Schimel, D. S., Braswell, B. H., Holland, E. A., McKeown, R., Ojima, D. S., Painter, T. H., Parton, W. J., and Townsend,
A. R.: Climatic, edaphic, and biotic controls over storage and turnover of carbon in soils, Global Biogeochem. Cy., 8, 279-293, doi:10.1029/94GB00993, 1994.

Schlesinger, W.: Carbon sequestration in soils: some cautions amidst optimism, Agr. Ecosyst. Environ., 82, 121-127, doi:10.1016/S0167-8809(00)00221-8, 2000.

Schlesinger, W. H. and Andrews, J. A.: Soil respiration and the global carbon cycle, Biogeochemistry, 48, 7-20, doi:10.1023/A:1006247623877, 2000.

Schulp, C. J. E. and Verburg, P. H.: Effect of land use history and site factors on spatial variation of soil organic carbon across a physiographic region, Agr. Ecosyst. Environ., 133, 86-97, doi:10.1016/j.agee.2009.05.005, 2009.

Senapati, N., Smith, P., Wilson, B., Yeluripati, J. B., Daniel, H., Lockwood, P., and Ghosh, S.: Projections of changes in grassland soil organic carbon under climate change are relatively insensitive to methods of model initialization, Eur. J. Soil Sci., 64, 229-238, doi:10.1111/ejss.12014, 2013.

Sleutel, S., De Neve, S., Hofman, G., Boeckx, P., Beheydt, D., Van Cleemput, O., Mestdagh, I., Lootens, P., Carlier, L., Van Camp, N., Verbeeck, H., Van De Walle, I., Samson, R., Lust, N., and Lemeur, R.: Carbon stock changes and carbon sequestration potential of Flemish cropland soils, Glob. Change Biol., 9, 11931203, doi:10.1046/j.1365-2486.2003.00651.x, 2003.

Smith, J., Smith, P., Wattenbach, M., Zaehle, S., Hiederer, R., Jones, R. J. A., Montanarella, L., Rounsevell, M. D. A., Reginster, I., and Ewert, F.: Projected changes in mineral soil carbon of European croplands and grasslands, 1990-2080, Glob. Change Biol., 11, 2141-2152, doi:10.1111/j.1365-2486.2005.01075.x, 2005.

Smith, P., Smith, J., Wattenbach, M., Meyer, J., Lindner, M., Zaehle, S., Hiederer, R., Jones, R. J. A., Montanarella, L., Rounsevell, M., Reginster, I., and Kankaanpää, S.: Projected changes in mineral soil carbon of European forests, 1990-2100, Can. J. Soil Sci., 86, 159-169, doi:10.4141/S05-078, 2006.

Sonneveld, M. P. W., and Van den Akker, J. J. H., Quantification of $\mathrm{C}$ and $\mathrm{N}$ stocks in grassland topsoils in a Dutch region dominated by dairy farming, J. Agr. Sci., 149, 63-71, doi:10.1017/S0021859610000535, 2011.

Sonneveld, M. P. W., Bouma, J., and Veldkamp, A.: Refining soil survey information for a Dutch soil series using land use history, Soil Use Manage., 18, 157-163, doi:10.1111/j.14752743.2002.tb00235.x, 2002.

Spek, T.: Het Drentse esdorpenlandschap. Een historischgeografische studie, PhD Thesis, Wageningen University, Wageningen, the Netherlands, 2004 (in Dutch).

Tranvik, L. J., Jansson, M., Evans, C. D., Freeman, C., Monteith, D. T., Reynolds, B., and Fenner, N.: Terrestrial export of organic carbon, Nature, 415, 861-862, doi:10.1038/415861b, 2002.

Trumbore, S. E., Chadwick, O. A., and Amundson, R.: Rapid exchange between soil carbon and atmospheric carbon dioxide driven by temperature change, Science, 272, 393-396, doi:10.1126/science.272.5260.393, 1996.

Unamuno, V. I. R., Meers, E., Du Laing, G., and Tack, F. M. G.: Effect of physicochemical soil characteristics on copper and lead solubility in polluted and unpolluted soils, Soil Sci., 174, 601610, doi:10.1097/SS.0b013e3181bf2f52, 2009.

Van den Berg, L. J. L., Sgotbolt, L., and Ashmore, M. R.: Dissolved organic carbon (DOC) concentrations in UK soils and the influ- 
ence of soil, vegetation type and seasonality, Sci. Total Environ., 427-428, 269-276, doi:10.1016/j.scitotenv.2012.03.069, 2012.

Van den Hurk, B., Klein Tank, A., Lenderink, G., Van Ulden, A., Van Oldenborgh, G. J., Katsman, C., Van den Brink, H., Keller, F., Bessembinder, J., Burgers, G., Komen, G., Hazeleger, W., and Drijfhout, S.: KNMI climate change scenarios 2006 for the Netherlands, KNMI Scientific Report WR 2006-01, KNMI, De Bilt, the Netherlands, 2006.

Van Engelen, A. F. V., Buisman, J., and IJnsen, F.: A millennium of weather, winds and water in the Low Countries, in: History and Climate, edited by: Jones, P. D., Ogilvie, A. E. J., Davies, T. D., and Briffa, K. R., Springer US, New York, 101-124, 2001.

Verheyen, K., Bossuyt, B., Hermy, M., and Tack, G.: The land use history (1278- 1990) of a mixed hardwood forest in western Belgium and its relationship with chemical soil characteristics, J. Biogeogr., 26, 1115-1128, doi:10.1046/j.13652699.1999.00340.x, 1999.
Vleeshouwers, L. M. and Verhagen, A.: Carbon emission and sequestration by agricultural land use: a model study for Europe, Glob. Change Biol., 8, 519-530, doi:10.1046/j.13652486.2002.00485.x, 2002.

Walmsley, D. C., Siemens, J., Kindler, R., Kirwan, L., Kaiser, K., Saunders, M., Kaupenjohann, M., and Osborne, B. A.: Dissolved carbon leaching from an Irish cropland soil is increased by reduced tillage and cover cropping, Agr. Ecosyst. Environ., 142, 393-402, doi:10.1016/j.agee.2011.06.011, 2011.

West, T. O. and Post, W. M.: Soil organic carbon sequestration rates by tillage and crop rotation: a global data analysis, Soil Sci. Soc. Am. J., 66, 1930-1946, doi:10.2136/sssaj2002.1930, 2002.

Worrall, F., Burt, T., and Shedden, R.: Long term records of riverine dissolved organic matter, Biogeochemistry, 64, 165-178, doi:10.1023/A:1024924216148, 2003. 